\title{
Ewa Woźniak, Ofiary i krzywdziciele. Studium postaci w przed- trydenckim piśmiennictwie pasyjnym. Analiza językoznawcza, Wydawnictwo Uniwersytetu Łódzkiego, Łódź 2007, ss. 328
}

Rozprawa Ewy Woźniak sytuuje się w obszarze semantyki tekstu. W obszernym (s. 7-39) Wstępie o charakterze teoretyczno-metodologicznym autorka gruntownie i wielostronnie charakteryzuje jej źródła (narracje biblijno-apokryficzne, kazania, medytacje, pieśni i modlitwy), podkreślając - mimo niejednorodności gatunkowej, odzwierciedlającej wielość form pobożności wszystko to, co je łączy (Jedność w wielości, czyli o źródtach, s. 7-21), a więc takie czynniki, jak temat (Męka Pańska), model nadawczo-odbiorczy (autorzy z kręgu wykształconego duchowieństwa, głównie zakonnego, przekaz skierowany do ewangelizowanego ogółu wiernych, co przesądza o przynależności tekstów do sfery kultury popularnej) czy zakres chronologiczny (teksty „złotej jesieni polskiego średniowiecza": od roku 1407 - pierwsza polska pieśn pasyjna - do 1577 - przyjęcie przez polski Kościół dekretów soboru trydenckiego na synodzie w Piotrkowie). Jak trafnie konkluduje aktorka: „O jedności podstawy materiałowej stanowi zatem temat pasyjny, przynależność do piśmiennictwa kościelnego (paraliturgicznego i pozaliturgicznego), typ założonego odbiorcy oraz zakres chronologiczny. Jest to jedność w wielości gatunków oraz form pobożności” (s. 21).

Cel rozprawy formułuje łódzka badaczka następująco: „W przedstawionym opracowaniu [...] dokonuje się, poprzez analizę językoznawczą, rekonstrukcji obrazu postaci w piśmiennictwie pasyjnym w określonym przedziale czasowym. Postaciami tymi są główni bohaterowie Męki Pańskiej. [...] Odtworzenie obrazu postaci nie stanowi jednak celu samego w sobie. Intencją autorki jest, by przedstawione studium bohaterów scen pasyjnych pogłębiało wiedzę o mentalności człowieka średniowiecza, o jego postrzeganiu świata, o postawie wobec podstawowych problemów egzystencji i transcendencji. Trzeba 
przyznać, że temat Pasji stwarza wyjątkową okazję do przyjrzenia się tym problemom z bliska" (s. 21).

Do osiagnięcia tak sformułowanego celu posłużyła autorce adekwatna do założeń rozprawy, synkretyczna metodologia. Badaczka wychodzi ze słusznego założenia, ,że człowiek, ujmując rzeczywistość za pomocą języka, tworzy (modeluje) pewien jej obraz: wyróżnia niektóre aspekty tej rzeczywistości, usuwając na drugi plan lub zupełnie pomijając inne. Wydobywane na plan pierwszy jest to, co dla człowieka ważne - dlatego mówi się, że poprzez język można dotrzeć do sposobów postrzegania i wartościowania przez człowieka rzeczywistości. W niniejszym opracowaniu te założenia dotyczące roli języka w modelowaniu obrazu rzeczywistości przenosimy na modelowanie obrazu postaci w tekstach. Nazywając pewne cechy i relacje, dokonuje się ich wyróżnienia, wyeksponowania. Działania te i ich rezultaty dobrze oddaje stosowana w kognitywizmie metaforyka «podświetlania»: z bogatego repertuaru różnych cech, które można przypisać osobom, «podświetla się» tylko niektóre i spośród różnych sfer aktywności osobowych bohaterów również «podświetla się» tylko niektóre - tak by uzyskać ich pożądany wizerunek" (s. 22). Zależy on od takich czynników, jak nadawca i jego punkt widzenia, tło podmiotowokulturowe czy tło stylowo-gatunkowe (ten czynnik autorka, z przekonującym uzasadnieniem, pomija w rozprawie). Z danych językowo-tekstowych Ewa Woźniak uwzględnia: system referencjalny (sposoby identyfikowania postaci), atrybuty oraz role semantyczne postaci w strukturze predykatowo-argumentowej. Przez te dane realizuje się modelowanie lub profilowanie (w rozumieniu lubelskiej szkoły etnolingwistycznej) postaci. Dominujący profil stanowi tekstową rolę semiotyczną - w wypadku postaci piśmiennictwa pasyjnego jest to rola ofiary albo krzywdziciela. Dodajmy, że role semiotyczne wyznaczają nadrzędny układ rozprawy: składa się ona z trzech części, z których pierwsza (s. 41-160) traktuje o ofiarach (Jezusie i Maryi), druga (s. 161-266) o krzywdzicielach (Judaszu, Żydach i poganach), a trzecia (s. 267-295) o ,innych” (Piłacie), natomiast w obrębie rozdziałów dotyczących poszczególnych postaci trzyczęściowy układ (system referencjalny, atrybuty i role semantyczne) określają dane językowo-tekstowe.

Ujmując rzecz najzwięźlej i zgodnie z deklaracją samej autorki, można by powiedzieć, że z semantyki lingwistycznej zaczerpnęła ona pojęcia struktury znaczeniowej i składników semantycznych, referencji i roli semantycznej argumentu w strukturze predykatowo-argumentowej, z tzw. semantyki rozumienia Jadwigi Puzyniny - koncepcję badań kontekstowych, a z językoznawstwa kognitywnego - pojęcia punktu widzenia, profilowania oraz metafory. Z przyjętej perspektywy badań i ze swoistości ich przedmiotu wynika, że analiza semantyczna ściśle się wiąże z analizą pragmalingwistyczną. Metodologiczny 
synkretyzm (czy, jak go określa autorka, pluralizm) traktuje Ewa Woźniak jako wymóg wynikający ze złożoności samego języka: bilateralnej natury znaku językowego i odzwierciedlających się w języku psychologicznych i społecznych uwarunkowań jego rozwoju. Odwołuje się w tym względzie do opinii Ewy Jędrzejko: „Nie ma dotąd - i ze względu na skomplikowany, wielorako uwarunkowany i ewolucyjny charakter języka naturalnego pewnie być nie może - jakiejś «jedynej» zasady wyjaśniania wszystkich jego aspektów w ramach jednej uniwersalnej teorii. Tylko wieloaspektowa analiza wielu faktów językowych pozwala wydobyć «obraz pojęcia» i wskazać treści nie zawsze uświadamiane właśnie dlatego, że język jest konwencją, którą sami kształtujemy, ale też poddani jesteśmy jej dyktatowi. Konieczne są więc różne lingwistyczne narzędzia" (s. 38).

Uzbrojona w scharakteryzowane wyżej instrumentarium badawcze, uzyskała łódzka lingwistka w swojej rozprawie ważne i interesujące wyniki naukowe. Do najwartościowszych zaliczyłbym następujące:

1. Potwierdzenie funkcji ewangelizacyjnych piśmiennictwa pasyjnego. Jak trafnie konstatuje autorka: „Poprzez odpowiednie wymodelowanie obrazu postaci przekazywano i utrwalano ważne teologiczne treści: o bóstwie i człowieczeństwie Jezusa, o zbawczej roli jego męki i śmierci, o dziewictwie i współodkupicielstwie Maryi. Są to te same treści, które w formie łatwej do zapamiętania, ale trudnej do pojęcia, komunikowały zwięzłe formuły tzw. wyznań wiary; są to też te same treści, które z kolei w formie przeznaczonej dla wykształconego odbiorcy przekazywały teologiczne traktaty" (s. 298).

2. Wykazanie, że piśmiennictwo pasyjne kształtowało sądy i oceny odbiorców nie tylko przez bezpośrednią perswazję, ale także nie wprost - drogą manipulacyjnego (w ocenie autorki) modelowania obrazu postaci, co jest najlepiej widoczne w sposobie ujęcia osoby Piłata (mechanizmy ukrytego wpływania na odbiorców prowadzą do uniewinniającej interpretacji jego roli) z jednej, a Żydów (i pogan) z drugiej strony (tu z kolei mechanizmy te skutkują obciążeniem winą za mękę i śmierć Jezusa świadomie i celowo działających Żydów).

3. Ustalenie, że „w przedstawieniach sfery psychicznej postaci obowiązuje zasada eksponowania tego, co uwidacznia się na zewnątrz, jest konkretne i wyobrażalne” (s. 298), a także przekonujące wykazanie, że „oceny dokonywane ze względu na różne typy wartości są ze sobą powiązane - ujemne$\mathrm{mu}$ wartościowaniu w kategoriach moralnych towarzyszy negatywna ocena w kategoriach estetycznych, poznawczych, a nawet odczuciowych. Mówiąc wprost: ktoś moralnie naganny nie może być piękny ani mądry, ani miły. Właśnie takiej jednoznaczności ocen wymagało ukształtowanie obrazu uwzględniające perspektywę prostego odbiorcy" (s. 298). 
4. Trafne spostrzeżenie stanowiące ważny przyczynek do zagadnienia źródeł antysemityzmu: „Poszukując - zgodnie z przyjętą perspektywą badawczą - «za słowami» i «za tekstami» obrazu przeszłości, znajdujemy tam, charakterystyczny dla epoki, obraz relacji wobec Żydów. Musiał to być stosunek bardzo niechętny, a nawet wrogi, skoro właśnie na tę zbiorowość przeniesiono całą odpowiedzialność za mękę i śmierć Jezusa. W przeprowadzonych analizach wykazano, że rolą krzywdzicieli obarczono w badanej grupie tekstów Judasza oraz Żydów. Takie wymodelowanie obrazu zbiorowości otwierało, jak sądzę, «furtkę» do usprawiedliwiania zachowań antyżydowskich" (s. 299).

5. Wykazanie zbieżności obrazu odtworzonego na podstawie danych językowych z przedstawieniami ikonograficznymi. Na przykład wyodrębnienie Judasza ze zbiorowości apostołów na poziomie językowym wyrażające się koniunkcją apostołowie i Judasz znajduje wyraziste „korelaty” ikonograficzne (autorka reprodukuje w książce miniatury ilustrujące izolację Judasza w czasie Ostatniej Wieczerzy). Podobnie językowemu obrazowi Judasza jako owładniętego przez szatana odpowiada fresk z Kaplicy Świętej Trójcy na zamku lubelskim, wyobrażający Judasza niosącego na plecach szatana.

6. Wykazanie korelacji między językowymi wykładnikami atrybutów postaci a ich atrybutami (rekwizytami) ikonograficznymi oraz między cechami wyróżnionymi w językowym obrazie postaci a cechami przypisywanymi im w ujeciach ikonograficznych (na przykład złu, chciwości i fałszywości (zdrajca) w językowym obrazie Judasza odpowiadają w przedstawieniach plastycznych: sakiewka za pasem, żółty kolor szat, rude włosy, kot, kruk, smok czy pies).

Ewa Woźniak kończy rozprawę słowami: „Autorce, po zakończeniu pracy, pozostaje żywić nadzieje, że osiagnie ona zamierzony cel: przyczyni się do zrozumienia dawnych tekstów i do zrozumienia przeszłości. A być może także zainspiruje współpracę językoznawców i historyków sztuki, bo - jak się wydaje - to pogranicze otwiera szczególnie interesujące perspektywy badawcze" (s. 300).

Recenzentowi wypada się podpisać pod tymi słowami obiema rękami. 